\title{
Peritidal cyclic sedimentation from La Manga Formation (Oxfordian), Neuquén Basin, Mendoza, Argentina
}

\author{
Ricardo M. Palma ${ }^{a, *}$, Diego A. Kietzmann ${ }^{\text {a }}$, Graciela S. Bressan ${ }^{\text {a }}$, Javier Martín-Chivelet ${ }^{\text {b,c }}$, \\ José López-Gómez $^{\mathrm{b}}$, María E. Farias ${ }^{\mathrm{d}}$, María P. Iglesias Llanos ${ }^{\mathrm{e}}$ \\ ${ }^{a}$ Universidad de Buenos Aires, Facultad de Ciencias Exactas y Naturales, Departamento de Ciencias Geológicas e CONICET-IDEAN, ${ }^{1428}$ \\ Buenos Aires, Argentina \\ ${ }^{\mathrm{b}}$ Instituto de Geociencias (CSIC,UCM), Madrid, Spain \\ ${ }^{\mathrm{c}}$ Facultad de Ciencias Geológicas, Departamento de Estratigrafia, Universidad Complutense de Madrid, Madrid, Spain \\ ${ }^{\mathrm{d}}$ PROIMI-CONICET, Laboratorio de Investigaciones Microbiológicas de Lagunas Andinas LIMLA, Argentina \\ ${ }^{\mathrm{e}}$ Universidad de Buenos Aires, Facultad de Ciencias Exactas y Naturales, Departamento de Ciencias Geológicas e CONICET, Argentina
}

a b s t r a c t

The La Manga Formation consists of marine carbonates and represents most of the sedimentary record of the Callovian-Oxfordian in the Neuquén Basin. Three localities in the southern Mendoza province were studied and their cyclicity was determined by means of facies analysis and their vertical arrangement. Facies of inner ramp, that were deposited in extremely shallow-water environments with intermittent subaerial exposures have been broken down into shallow subtidal, and intertidalesupratidal environ-ments. Shallow subtidal facies are arranged into decimetre scale upward-shallowing cycles composed of marls, laminated or massive mudstones or bioclastic wackestones and intraclastic wackestone-pack-stones. Intertidal-supratidal centimetre-scale cycles consist of an upward-shallowing succession of restricted facies, overlaid by horizontal or crinkle microbial laminites, flat pebble conglomerates or breccias beds. The defined cycles show a shallowing upward trend in which the evidence of relative sea-level lowering is accepted. The interpretation of Fischer plots allowed the recognition of changes in accommodation space.

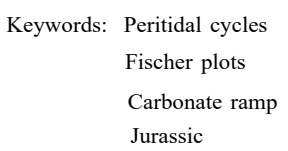

\section{Introduction}

Shallow water carbonate facies usually show cyclic vertical arrangements of facies that can result from both autocyclic and allocyclic processes, or more commonly, a combination of both. These cycles show vertical changes in their forming facies, as well as in their thicknesses, mostly controlled by longer-term accom-modation changes (e.g., 3rd order sea level changes). The study of these stratigraphic patterns in peritidal cycles commonly consti-tutes a robust tool for reconstructing variations in accommodation in shallow water settings, in where the water surface usually de-fines de base level, and the carbonate production commonly exceeds the generation of space for accumulation. In this paper we present a case study of this type of cyclicity in a Jurassic carbonate

\footnotetext{
* Corresponding author. Tel.: b54 1145763329.

E-mail addresses: palma@gl.fcen.uba.ar, ricpalma77@hotmail.com (R.M. Palma),

diegokietzmann@gl.fcen.uba.ar (D.A. Kietzmann), gbressan@gl.fcen.uba.ar (G.S. Bressan), j.m.chivelet@geo.ucm.es (J. Martín-Chivelet), jlopez@geo.ucm.es (J. López-Gómez), mefarias@proimi.org.ar (M.E. Farias), mpiglesia@gl.fcen.uba.ar (M.P. Iglesias Llanos).
}

ramp in the Neuquén Basin (Argentina), in which the character-ization of cycle stacking patterns will contribute to a better un-derstanding of the evolution of the carbonate platform and the sedimentary basin.

In the Neuquén Basin, the Callovian-Oxfordian time was char-acterized by widespread carbonate deposition in ramp systems with environments ranging from the outer ramp to the tidal flat. All these carbonates today conforms the so-called La Manga Formation (Stipanicic, 1965), exceptionally exposed in the west-central area of Argentina. Studies of the La Manga Formation have been mainly focused on its lithostratigraphy, biostratigraphy and paleontology (Stipanicic, 1965; Leanza, 1981; Riccardi, 1984, 1992), as well as on sedimentological interpretations (e.g., Legarreta, 1991; Lo Forte and Palma, 2002; Bressan and Palma, 2010; Palma et al., 1997, 2007, 2009, 2011) and diagenetic aspects of the succession (Palma et al., 1997). Despite these previous studies, little attention has been paid to peritidal facies and small-scale cycles, which appears in different areas at the top of this formation. These facies had not been previously recognized and have been highlighted recently by Palma et al. (2010, 2011). Complex facies distribution is inherent to 
this unit, these being largely controlled by different depocenters of the Neuquén Basin (e.g., Palma et al., 2007, 2009, 2010).

Stratigraphic studies conducted by the authors allowed to recognize the existing facies variations and the remarkable pecu-liarity and preservation of microbial carbonates. The presence of these microbial deposits and the abundant evidence of subaerial exposure and facies stacking patterns, allowed us to recognize different types of cycles.

The origin and frequency of peritidal carbonate cycles have been explained based on three main processes that can generate changes in accommodation space: a) eustatic changes (e.g., Goldhammer et al., 1987; Strasser et al., 1999), b) high-frequency repetitive var-iations in local subsidence (Cisne, 1986), and c) autocyclic processes (Ginsburg, 1971; Pratt, 2010). In the first two cases, the ultimate factor controlling cyclicity is external to the depositional system (eustasy, tectonism), whereas in the third situation the factor is inherent to that system, and mainly determined by changes in carbonate production. However, it is important to keep in mind that autocyclic and allocyclic processes can act together or one may dominate over the other.

As it is known, carbonate production is controlled by climatic, eustatic and tectonic processes, among other phenomena (Schlager, 2003). In any case, it is possible to recognize different stacking patterns in the stratigraphic record, which may be influenced or controlled by variations in the carbonate production (Carpentier et al., 2010).

In this paper we present the results of an integrated sedimen-tological study, from outcrop to microscopic scale on a well pre-served middleupper Oxfordian peritidal carbonate succession in the upper part of $\mathrm{La}$ Manga Formation in the south of Mendoza province. The aim of this study is to improve the understanding of the paleoenvironmental evolution of the La Manga Formation in three localities (Arroyo La Manga, Los Blancos and Yeseras Grandes). Additional data come from other sections known as Codo del Blanco and Arroyo La Vaina (Fig. 1). In order to provide a detailed account of cyclicity facies, and their vertical distribution, we propose an interpretation of the depositional environment discussing the likely mechanisms that caused cyclic sedimentation. The study documents the presence of decimetric to centimetric cyclicity on the shallow subtidal and intertidal-supratidal deposits, and the vertical organization of different types of cycles. It is noteworthy that each one corresponds to a minor variation inside the shallowing-upward sedimentary trend. The use of "Fischer plot" technique allowed us to recognize changes in accommodation space and the correlation among the studied sections.

\section{Stratigraphic framework}

The Neuquén Basin, located at the western margin of the South American platform, is limited by a magmatic arc to the west and a tectonic foreland to the east. The foreland consists of the Sierra Pintada belt to the northeast and the North Patagonian massif to the south. The Neuquén Basin is a typical retro-arc basin that developed to the east of the Cordillera Principal between $36^{\circ} \mathrm{S}$ and $39^{\circ} \mathrm{S}$. The most important works describing the geologic setting of the region include those by Groeber et al. (1953) and Mitchum and Uliana (1985). Legarreta and Gulisano (1989) described four tec-tonic episodes of basin development: 1- rifting (Upper Triassic-Lower Jurassic), 2- thermal subsidence (Lower Jurassic-Upper Cretaceous), 3magmatic subsidence and loading (Upper Cretaceous-early Tertiary) and 4Andean tectonism (early Tertiary-Quaternary).

The basement consists of Early Paleozoic to Late Triassic metamorphic, plutonic, volcanic, and sedimentary rocks. Groeber (1946) identified three depositional cycles: Jurásico, Ándico and

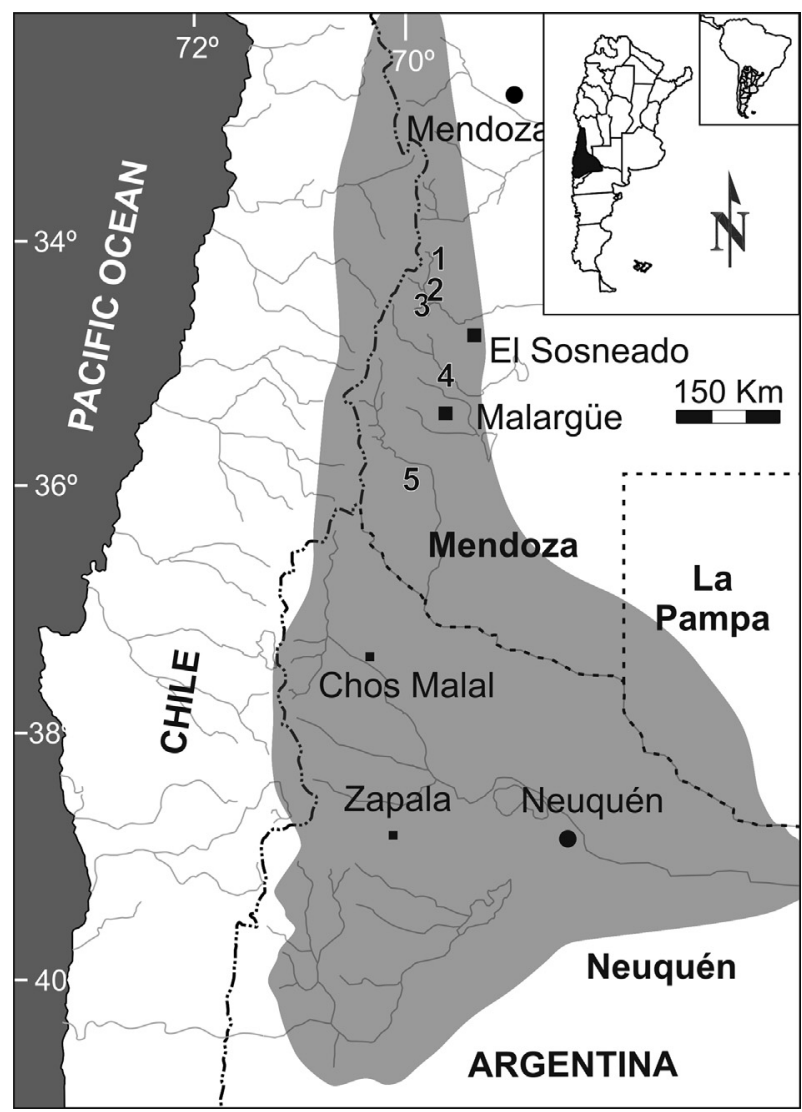

Fig. 1. Location map of the Neuquén Basin with indication of the studied localities: (1) Yeseras Grandes; (2) Arroyo La Manga; (3) Codo del Blanco; (4) Los Blancos; (5) Arroyo La Vaina.

Riográndico. Legarreta and Gulisano (1989) agreed generally with the validity of the Groeber's cycles, and emphasized the importance of eustatic variations in the development of depositional se-quences. In the Neuquén Basin different depocenters resulting from the basin evolution were recognized (Manceda and Figueroa, 1995). Our study is based on stratigraphic sections from the Atuel, Valenciana and Malargüe depocenters, located in the northern sector of the basin (Giambiagi et al., 2008).

The Jurassic sequences are part of the Lower Supersequence of Legarreta and Gulisano (1989), which includes three meso-sequences: Precuyo, Cuyo and Lotena. The Precuyo Mesosequence (Upper TriassicSinemurian) consists of non-marine siliciclastic and volcanic deposits. The early Sinemurian to early Callovian deposits are known as Cuyo Mesosequence (Legarreta and Gulisano, 1989) which is composed mainly of marine siliciclastic deposits. The Lotena Mesosequence comprises five depositional sequences that include marine and continental facies (Lotena Formation), car-bonate deposits (La Manga Formation), and evaporites (Auquilco Formation). The age of the Lotena Mesosequence was considered as lower Callovian to middle Oxfordian (Palma et al., 2012).

\section{Stratigraphic succession}

The La Manga Formation includes most of the sedimentary record of the Callovian-Oxfordian interval in the northern Neuquén Basin, and represents the middle part of the Lotena Mesosequence (Fig. 2).

The age of this unit is well defined by an ammonite assemblage, indicating an early Callovian to middle and late Oxfordian age for 


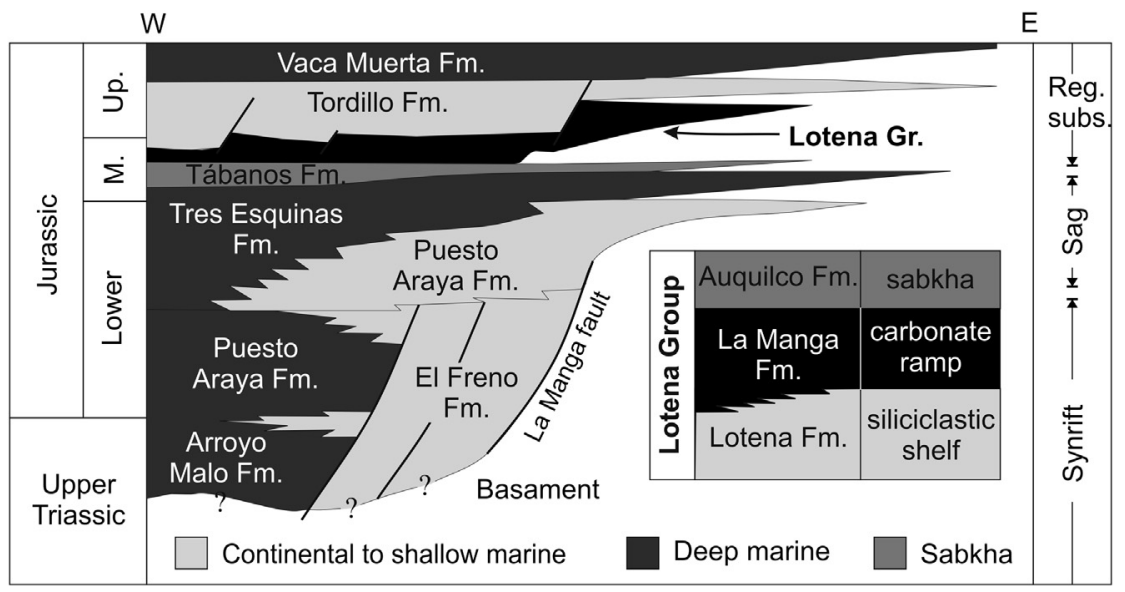

Fig. 2. Jurassic chronostratigraphic framework of the Neuquén Basin in the south of the Mendoza province. Atuel depocenter (after Giambiagi et al., 2008).

these deposits (Palma et al., 2012). Ammonites collected (Palma et al., 2007, 2009, 2011, 2012) have been identified in all the peri-tidal studied sedimentary sections. These ammonites include Per-isphinctes (Arisphinctes) sp. Perisphinctes (?Kranoosphinctes) sp. and Mirosphinctes sp., which belong to the middle Oxfordian Peri-sphinctes-Araucanites Zone (Riccardi, 2008).

Although the Late Jurassic ammonite fauna from La Manga Formation is still insufficiently known and poorly documented, ammonites have proved to be the prime tool for biozonation and correlation.

According to their distribution along a north-south transect, these outcrops will be mentioned here as Yeseras Grandes (west of the small town of El Sosneado), Arroyo La Manga and Los Blancos (close to the Salado River) (Fig. 1).

Carefull field observations allowed confident reconstructions of the depositional sequence (Palma et al., 2007, 2009, 2010, 2011). For description purposes, the studied successions have been sub-divided into two informal units (Palma et al., 2012). Unit 1, the lower one, corresponds to outer ramp facies. Unit 2, the uppermost part, corresponds to inner ramp deposits (shallow subtidal to intertidal-supratidal facies) and is the focus of this work. It should be noted that a similar outer-ramp to inner-ramp evolution has been previously described from La Manga Formation in other areas of the basin (Legarreta and Gulisano, 1989; Legarreta, 1991; Palma et al., 2007). Nevertheless, local differences on the facies controlled by intrabasinal factors have been observed.

The La Manga Formation is well exposed in the five studied localities (Fig. 1) and shows a variety of carbonate deposits. Thick-ness of the complete succession in the studied areas varies from $23 \mathrm{~m}$ in Los Blancos to $25 \mathrm{~m}$ in the Yeseras Grandes, and increases in the Arroyo La Manga, reaching about $53 \mathrm{~m}$. Thickness of Unit 2 measured in the different localities are as follows: in the Los Blancos section it reaches $23 \mathrm{~m}$ while in the Arroyo La Manga and Yeseras Grandes it reaches $12 \mathrm{~m}$ (Fig. 3). In other localities, as Codo del Blanco and Arroyo La Vaina, the thickness changes to 11 and $10 \mathrm{~m}$, respectively. These peritidal deposits have not been mentioned before, except references made by Palma et al. (2010, 2011, 2012).

In order to document the facies development and evolution of the Unit 2 of the La Manga Formation three sections were measured bed-by-bed. Sedimentary structures and bedding fea-tures (thickness trends, cycles) were recorded and integrated into the facies analysis. Rocks were sampled for microfacies analysis (60 thin-sections) and classified according to deposi-tional texture.
4. Sedimentary facies and depositional system

\subsection{Shallow subtidal facies}

\subsubsection{Description}

Most subtidal sediments are mudstones, wackestones and wackestoneepackstones. Occasionally these facies appear inter-bedded with marls and shales (Fig. 4A).

Mudstone facies, frequently argillaceous, shows planar lamination or appear massive. It crops out in beds with thickness ranging from 5 to 20 $\mathrm{cm}$. Greenish to brownish calcareous laminated to massive shales and marls are also present. They range in thickness from 5 to $20 \mathrm{~cm}$ and include millimetre-thick mudstone layers or lenses.

Bioclastic wackestone facies occurs in beds with thickness ranging from 7 to $20 \mathrm{~cm}$. They are dark grey typically massive or laminated beds. Beds are interbedded with massive or laminated grey to brownish marls or shales, and show either sharp or erosional bases. The wackestones include small disarticulated and fragmented gryphaeid shells, scattered forams, as well as fragments of green algae and echinoid fragments (Fig. 4B). Moreover, peloids, oncoids and small intraclasts are also common. The oncoids are ameboidal to ellipsoidal in shape. Lamination is apparent in some oncoids whereas it is less apparent in others due to micritization, that also affected bioclasts.

Intraclastic wackestone facies occurs in beds with thickness ranging from 10 to $23 \mathrm{~cm}$. They are dark grey and typically massive beds composed of flat, subangular to angular unsorted microbial intraclasts, ranging in diameter from 0.1 to $0.4 \mathrm{~cm}$. Besides, evap-oritic pseudomorph crystals are common. Intraclastic wackestone facies lateral variability make difficult to correlate particular hori-zons across the stratigraphic sections.

Bioclastic intraclastic wackestoneepackstones with herring-bone crossstratification are recognized in Arroyo La Vaina (Fig. 4C). Beds are thin $(20 \mathrm{e} 35 \mathrm{~cm})$ and laterally discontinuous and grade up to bioclastic wackestones. Bioclasts are represented by gryphaeid, echinoid, and gastropod fragments and most of them are affected by intense micritization. Subangular intraclasts of wackestones and planar microbial laminites also appear in this facies.

\subsubsection{Interpretation}

Shallow subtidal deposits include shale, marls, mudstones, wackestones and wackestoneepackstone facies. The predominance of mud supported textures and low diversity of skeletal fauna support the interpretation of this section as calm shallow subtidal environments. 


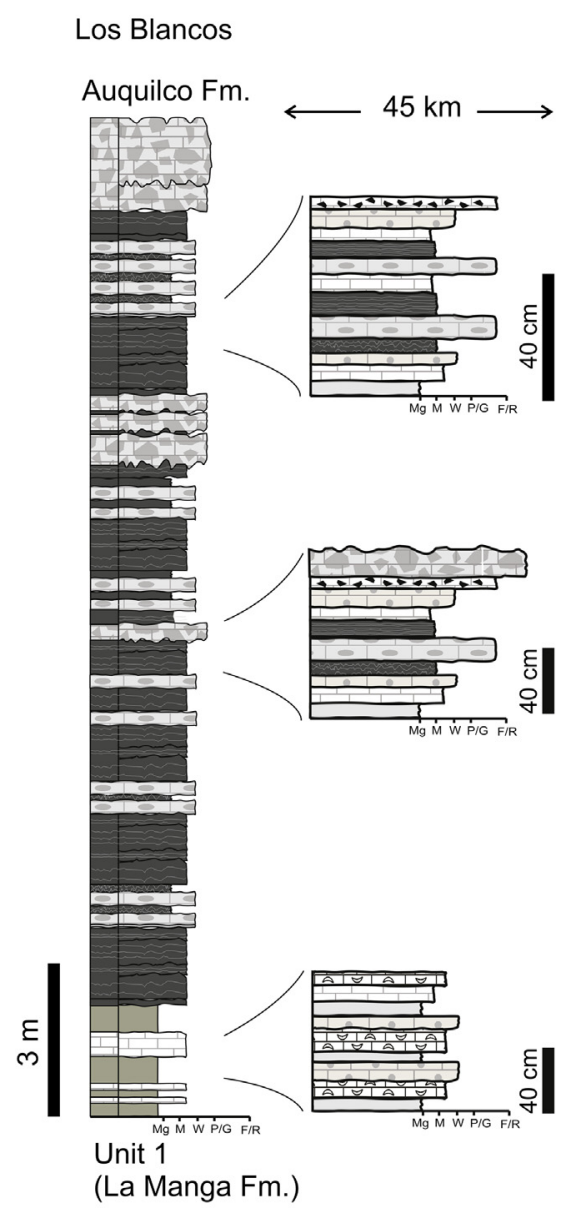

Arroyo La Manga

Auquilco Fm.

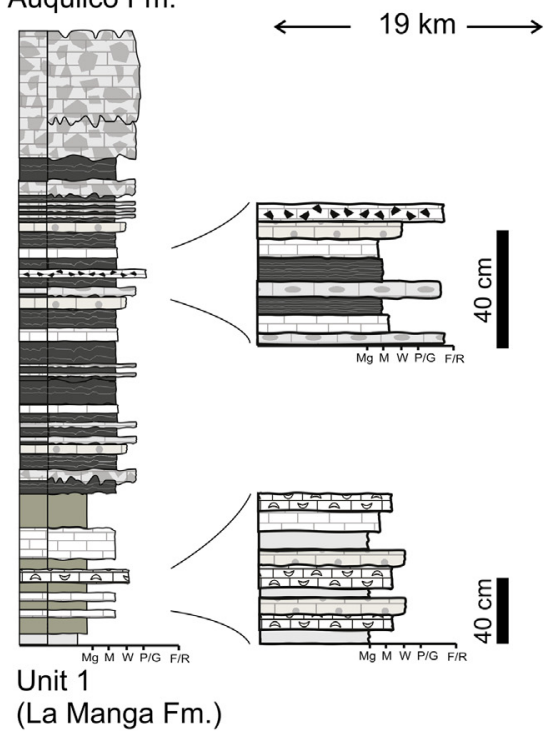

Yeseras Grandes

Auquilco Fm.

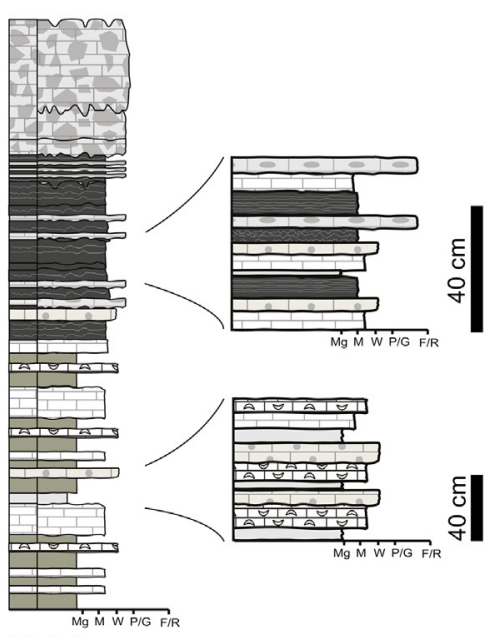

Unit 1

(La Manga Fm.)
Lithological references

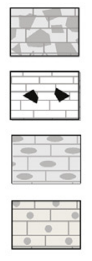

Paleokarst breccias

Intraclastic breccias

Flat pebbles conglomerates

Intraclastic wackestones
Bioclastic wackestones

Mudstones

Microbial laminites

Marls

Fig. 3. Simplified lithological log of the three studied sections and some principal cycles indicating texture and facies. For discussion refer to text. Interval distance (in km) between sections is noted. Sections located in Fig. 1.

Bioclastic wackestones are interpreted to represent an open to restricted shallow subtidal environment with influence of relatively low current energy. Dasycladaceae algae, mostly Acicularia sp.(Palma et al., 2007), Cayeuxia sp., bivalves and echinoderms suggest open marine circulation, however miliolids, ostracods and gastro-pods probably represent restricted marine circulation (Palma et al., 2007). Shale and marl facies were deposited from suspension in a low energy setting, indicating that the finegrained sediment was not winnowed away by currents or waves, while the scarcity of fossils suggest a high-stress inhospitable environment.

The presence of subangular to angular intraclasts indicates intermittent wave or storm-wave action that would have favoured the erosion and transport of intraclasts from early cemented sub-strates. In addition, most peloids of this facies are thought to have been formed by shrinking of original microbial laminites and muddy laminae owing to desiccation and/or salinity variations (Carillat et al., 1999).

Broken bioclasts and algae have been transported by the action of currents. Tidal influence is clearly visible in the rare wackestoneepackstones with herringbone cross-stratification suggesting a shallow subtidal setting influenced by moderately high energy conditions. Herringbone cross-stratification clearly points to reverse currents in a shallow water small channel (Fig. 4C).

The presence of evaporite pseudomorphs on the top of intra-clastic wackestone facies suggests a diagenetic replacement of evaporite crystals during an early stage of diagenesis and resulted in complete dissolution of gypsum and its gradual replacement by calcite. Dissolution of sulphates, evidenced by pseudomorphs, and pervasive calcitization of them took place in consequence of fresh water influx (Dean and Anderson, 1982).

Finally, taking into account fossil content and depositional fea-tures a shallow subtidal environment under low to moderate en-ergy conditions is suggested.

\subsection{Intertidal to lower supratidal facies}

\subsubsection{Description}

These deposits are represented by conspicuous planar to crinkly microbial laminite beds interbedded with mudstones and wackestones, flatpebble conglomerates, intraclastic breccias and remarkable paleokarst breccias.

Mudstone facies, rich in peloids, shows planar lamination or normal grading on a centimetre-scale and contains pseudomorphs of evaporite crystals. Mudstone beds, range in thickness from 2 to $5 \mathrm{~cm}$. This facies alternates with planar microbial laminites or flat-pebble conglomerate beds (Fig. 4D).

Wackestone facies consists of sharp or erosional based massive or laminated wackestones ranging in thickness from 6 to $25 \mathrm{~cm}$ (Fig. 4E). Wackestones appear weakly bioturbated and, more rarely, with ripple lamination. Centimetric scoured bases show intraclasts, while some tops appear with evidence of subaerial exposure such as mud-cracks. Wackestone facies are rhythmically interbedded with thin flat-pebble conglomerates or carbonate breccias, as well as with planar to crinkly microbial laminites 

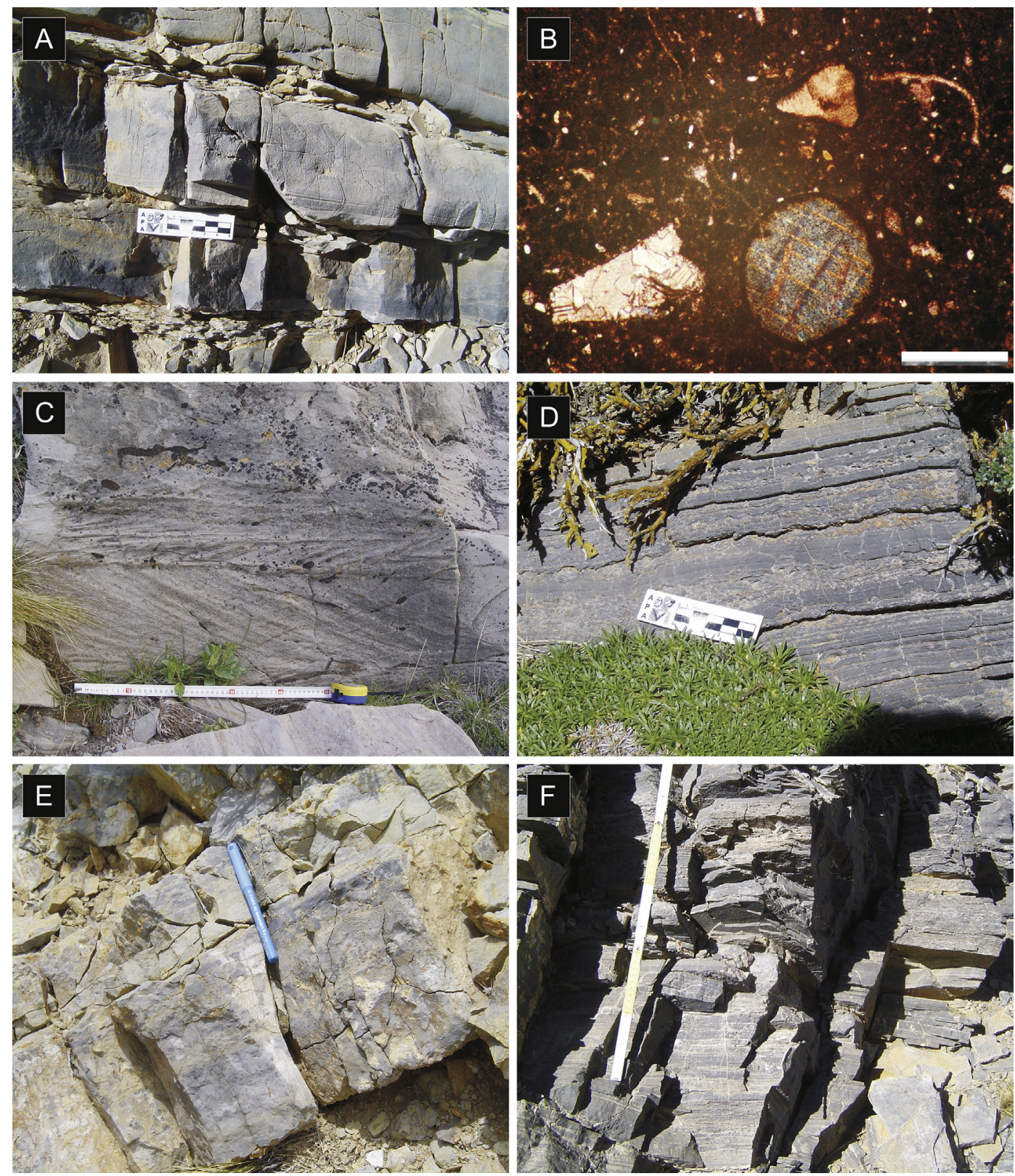

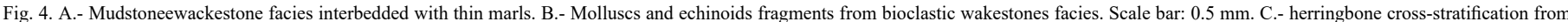

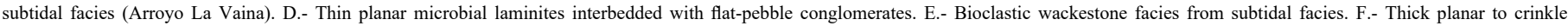
microbial laminites facies from intertidal-supratidal facies.

facies. Wackestone facies also contain pseudomorphs of evaporite crystals.

Microbial laminites facies were divided into two subfacies on the basis of presence or absence of subaerial exposures. This facies ranges from flatlaminated to crinkled forms. They form beds from 2 to $80 \mathrm{~cm}$ thick and, although some can be traced through tens of metres, most of them pinch out laterally (Fig. 4F).

The internal architecture of the microbial beds is highly variable. They show planar to wavy-lamination with microcrystalline calcite. The lamination is most pronounced where black and grey macro-laminae, up to $2 \mathrm{e} 3 \mathrm{~mm}$ in thickness, alternate with submillimetric laminae.

Some of the microbial crinkled laminae appear to have been partially turn-up, while still in a soft nonlithified state. Similar characteristics were observed on modern cyanobacterial flats in the
Ras Muhammad pool in the intertidal to supratidal zone by Friedman et al. (1985).

Crinckly microbial laminites commonly contain abundant distinctive features, such as micro-tepees, laminar and subcircular fenestrae, mud-cracks, and sheet-cracks (Fig. 5A). Several bedding planes showed desiccation cracks, where poligons vary in size be-tween 2 and $15 \mathrm{~cm}$. In cross section small vertical cracks show delicate walls, while are rarely V-shaped. Sheet-cracks are more commonly present in the microbial sediments.

Tepees are characterized by small antiform deformation struc-tures. These structures are very small, between 0.10 and $0.20 \mathrm{~cm}$ in size. Subcircular and laminar fenestrae pores were distinguished. The latter could be characterized by a flat bottom and irregular top, and appear aligned according to the bedding planes. Usually, microbial laminites are overlain by breccia facies or flat-pebble conglomerates. 

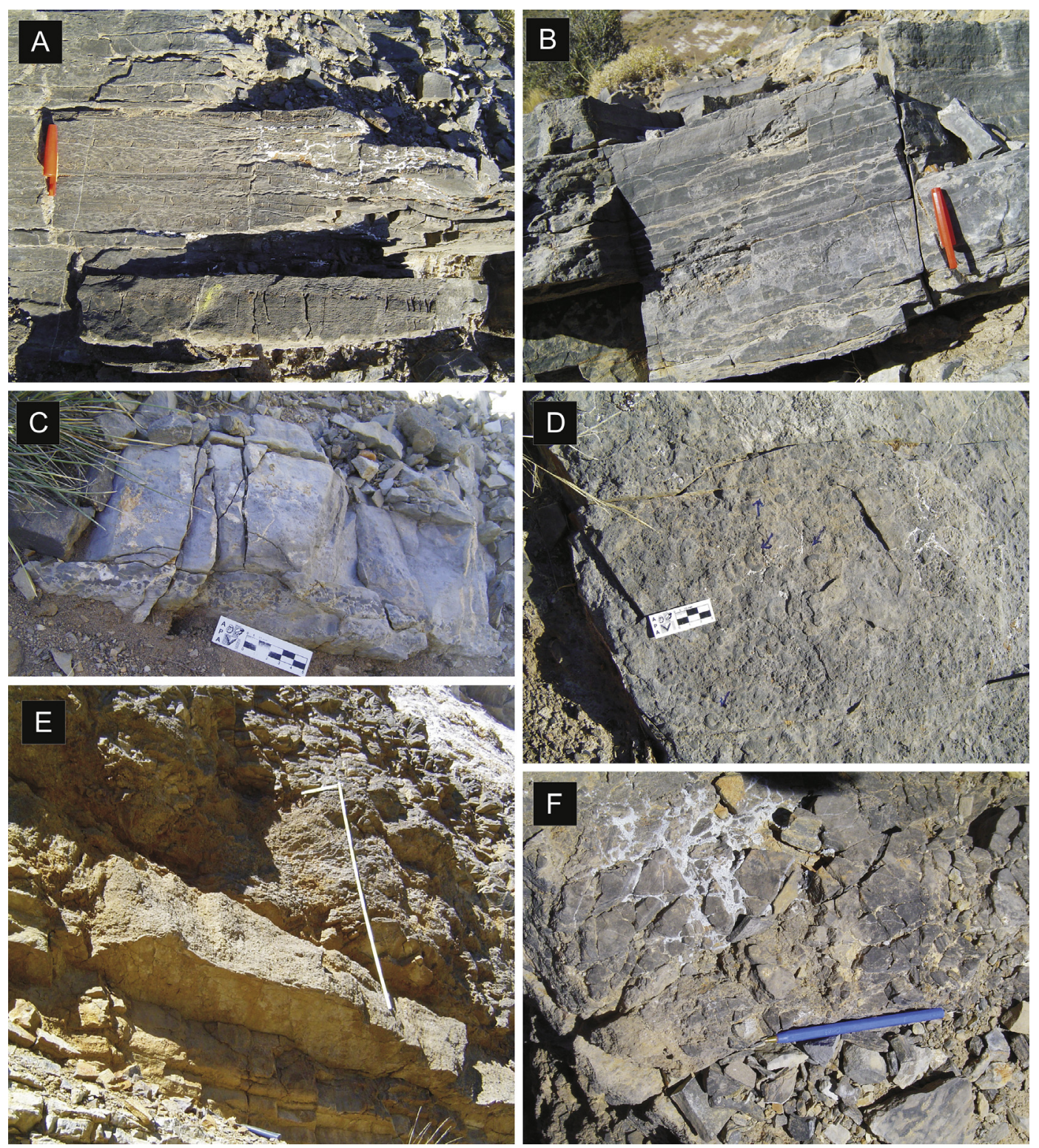

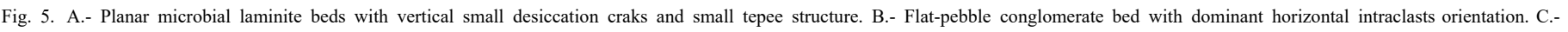

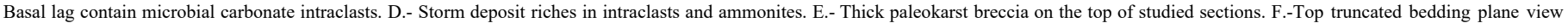
of autoclastic breccia.

Flat-pebble conglomerates (FPC) consist of rip-up clasts derived from underlying planar to crinkle microbial beds (Fig. 5B). They range from clast- to matrix-supported laterally discontinuous de-posits, which vary in thickness between 4 and $30 \mathrm{~cm}$. Tops and bases of strata are typically planar, but erosional and irregular contacts are also common. FPC lies unconformably over the planar to crinkle microbial carbonate facies. The composition of these intraclasts is very homogeneous, represented by microbial lam-inites, but some mudstoneewackestone intraclasts are also present.

Subangular to angular planar microbial clasts appear as discrete and discontinuous or parallel and continuous to bedding. In many cases these intraclasts show a completely random distribution or may have a slight imbrication. Addi-tionally, reworked mat chips increase up section. Flat-pebble conglomerates are commonly associated with desiccation mud-cracks and tepees.
Dark to grey intraclastic breccias (lag) (Fig. 5C) are present as laterally discontinuous beds with scoured base, and as lenses or small channel fills. Beds thicknesses range between 5 and $12 \mathrm{~cm}$. Breccias are massive and are interbedded with microbial laminites or flat-pebble conglomerate beds. Intraclasts are of microbial car-bonate composition. In the intraclastic breccia facies well preserved ammonite shells and echinoids were found. The ammonites have been identified as Mirosphynctes sp. (Fig. 5D) (Riccardi, pers.comm.).

The top of the three sedimentary sections show a mantiform breccia originated by karstic processes. Paleokarst breccias consist of calcareous chaotic clast-supported deposits. Clasts of breccias are angular with a fitted clast texture to extreme brecciation, showing highly variable textures from silt to cobble size. The petrographical composition of the clasts is consistent with the underlying facies previously described (Fig. 5E,F). Small dissolution cavities in size from 1 to $3 \mathrm{~cm}$ have been recognized. Thickness of the paleokarst 
breccias reachs $1.60 \mathrm{~m}$ (Yeseras Grandes), $2.00 \mathrm{~m}$ (Arroyo La Manga) and $1.86 \mathrm{~m}$ (Los Blancos).

\subsubsection{Interpretation}

Intertidal-lower supratidal settings are represented by micro-bial laminate beds interbedded with mudstoneewackestones, flat-pebble conglomerates, intraclastic breccias and paleokarst breccias. Planar to crinckle microbial beds record the trapping by microbial mats of fine grained sediments settled down from the water after the storms in this setting. The presence of convex-up laminae growing on planar or crinkly laminae could be related to the sedi-ment cohesion. Crinkly lamination with fenestral pores indicates episodic exposure and desiccation and associated features such as sheet-cracks and mudcracks. These evidences suggest temporary emergent conditions or hiatuses indicative of variations in salinity (Husinec and Read, 2011).

Bioturbation was observed only in a single horizon in the upper part of the microbial surface (Palma and Kietzmann, 2008). More-over, as additional feature, microbial laminites are not dolomitized, probably as consequence of lightly more humid conditions, similar to those mentioned by Grover and Read (1978). Studies realized on stratiform microbial laminites from tidal flats in the Arabian Gulf and Shark Bay (Kendall and Skipwith, 1969; Davies, 1970) showed similar environmental setting as seen in the La Manga.Formation.

Tepee structures are common in the intertidal-supratidal settings. These structures are the result of frequent episodes of crustal cracking caused by both thermal expansion and changes in the position of the water table (Kendall and Warren, 1987). According to Assereto and Kendall (1977) these structures can be considered as immature tepees. Similar structures occur in the Holocene of southern Australia (Warren, 1982) and Arabian Gulf (Assereto and Kendall, 1977).

The origin of irregular fenestral pores is commonly associated to the molds of cyanobacterial mats buried by sediment or to desic-cation and propagation of horizontal sheet-cracks (Demicco and Hardie, 1994). Studies in recent microbial laminites show that planar to crinkle microbial mats grow frequently above mean low water level or tidal flats which are periodically flooded and exposed (Reid et al., 2011).

Bedding surfaces of the flat-pebble conglomerate layers (FPC) show irregular flat polygons which indicate that the fragmentation was as consequence of desiccation. The origin of the FPC facies is related to erosion and redeposition by storms (Shinn, 1983) of desiccated microbial mats during the marine flooding on top of the laminated facies. As was mentioned before, the presence of continuous and discontinuous layers of rip-clasts with random distribution are interpreted as the result of complete reworking of mud cracked microbial beds by current activity and storm events, which is also evidenced by scoured bottom and intraclasts. Actually, on some tops of this facies, the presence of abundant ammonites (Mirosphynctes sp.), and regular echinoderms (Palma and Kietzmann, 2008; Palma et al., 2011) is direct evidence of storm-wave action. The sedimentary features overall suggest deposi-tional processes resulting from sudden episodes of higher hydro-dynamic energy.

According to evidence this sedimentary succession is interpreted as mainly low energy, very shallow intertidal-supratidal, restricted marine setting, affected by high energy storm events, as suggested by the presence of open marine fauna such as ammonites and nannofossils such as Cyclagelosphaera sp. (middle Oxfordian in age, Concheyro, pers.comm.).

The intraclastic breccias represent a mix of fragments ripped up by storm-wave action and local autoclastic breccias generated by prolonged subaerial exposure in the upper intertidal-supratidal area (Fig. 5F).
Different episodes of subaerial exposure are evidenced by microkarst and paleokarst surfaces on the intertidal-supratidal setting. Small dissolution cavities are interpreted as microkarsts, while breccias from several centimetres to metres in thickness also suggest prolonged exposure and dissolution of evaporites (paleokarst). These surfaces may represent missed beats of relative change of sea level. Actually, before the beginning of deposition of the evaporites of the Auquilco Formation, a subaerial episode that resulted in an extensive paleokarst surface is recognized in several areas (Palma et al., 2012).

\section{Analysis of cyclicity}

The vertical facies evolution and the variation of sedimentary structures related with emersion features allow us to recognize subtidal and intertidal-supratidal cycles. These are almost exclu-sively of centimetre to decimetre scale. The cycle boundaries are recognized by changes in the depositional environment above and below the contact, and the presence of erosion and subaerial exposure features. The upward increase in average grain size (autoclastic breccia and flatpebble conglomerate on the top) indicate a progressive shallowing tendency, which is also evi-denced by the presence of planar to crinkle microbial laminites and tepee structures. Continued shallowing favored the development of microbial communities in response to decreased water depth, commonly bounded by erosion surfaces or subaerial exposures features. Five different types of sedimentary cycles are recognized in the measured sections (Fig.6).

\subsection{Shallow subtidal cycles (Type A)}

Cycles start with a sharp surface which is overlain by marls, followed by laminated or massive mudstones, bioclastic wackestones and intraclastic wackestones, where an increase in size and abundance of intraclasts are observed.

A variation of this cycle is observed in Arroyo La Vaina, starting with bioclastic-intraclastic wackestoneepackstones with herring-bone cross-stratification which are overlain by bioclastic wacke-stones and passing upwards through gradational contacts into intraclastic wackestones at the top of these cycles (Fig. 6A). These coarsening upward cycles varies from 9 to $36 \mathrm{~cm}$ with an average of $20 \mathrm{~cm}$. At this part there is evidence of exposure related features such as evaporite pseudomorphs crystals.

The presence of bivalves, echinoderms and gastropods in shallow subtidal settings suggest periodic improvement in the environment conditions. The lagoon regularly becomes exposed as shown by the occurrence of mud-cracks and evaporite pseudomorphs on the top of wackestone facies. Evidence for a shallowingupward trend of these cycles included an upward decrease in fossil content, but also an increase in intraclasts and occurrence of pseudomorphs of evaporite crystals.

Taking into account the presence of marine biota as well as the occurrence of calcareous green algae (Palma et al., 2007) these cycles would be deposited in a shallow subtidal lagoon setting with well oxygenated waters. Herringbone cross-stratification implies reversing currents in the small channel. The presence of micro-oncoids suggests very shallow subtidal setting (Gebelein, 1976) and the intraclasts of subtidal origin might reflect rework-ing by waves or currents. The presence of basal lags rich on mi-crobial laminites intraclasts in the base of subtidal cycles would be related with reworking occurred during storms. The finning up-ward facies indicate that these lags probably correspond to washover expanding into the protected lagoon and intertidal set-tings (cf. Bádenas et al., 2010). Moreover, during the storms, shell debris of marine organisms would be transported and washed 


\section{SHALLOW SUBTIDAL CYCLES (A)}

A

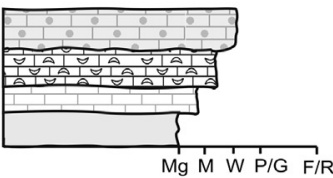

INTERTIDAL-SUPRATIDAL CYCLES (B)

B Cycle B1

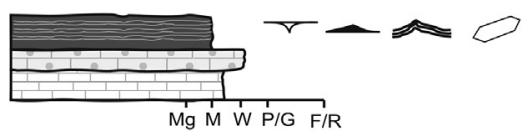

C Cycle B2

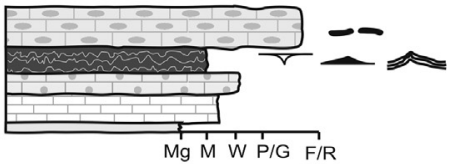

D Cycle B3

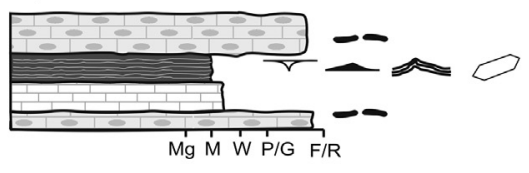

\section{Lithological references}

Intraclastic breccias

Flat pebbles conglomerates

Intraclastic wackestones

Bioclastic wackestones

Mudstones

Microbial laminites

Marls

\section{E Cycle B4}

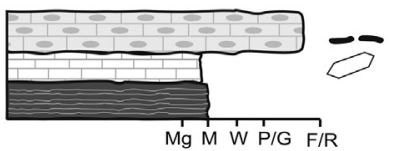

F Cycle B5

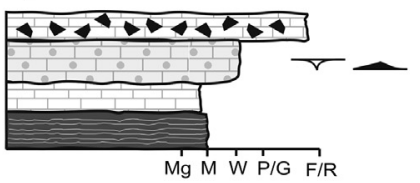

Sedimentary structure references

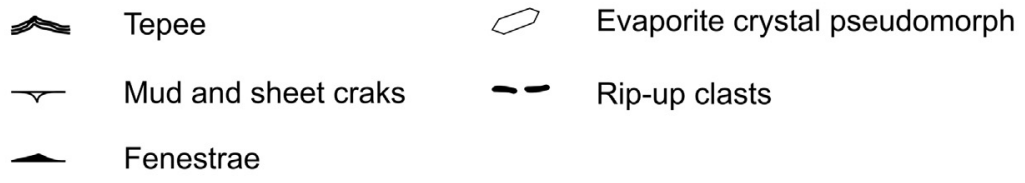

Fig. 6. Main cycles types recognized in the studied sections. See text for description.

from the shallow subtidal to the intertidal-lower supratidal environments.

\subsection{Intertidal-supratidal cycles (Type B)}

The most common cycles are shallowing-upward cycles, and different types were observed.

\subsubsection{Cycle B-1}

This is the most common cycle type that dominates all the studied sections (Fig. 6B). These cycles start with a planar erosion surface overlain by thin marls or massive mudstones from the subtidal setting, followed by intraclastic wackestones. The cycle is capped by planar or crinkle microbial laminate beds with fenestrae, mud-cracks, sheet-cracks and evaporite pseudomorph crystals. Occasional tepees and microkarstic breccias are also present.

\subsubsection{Cycle B-2}

These cycles are similar to B-1, but include intraclastic breccias at their uppermost part (Fig. 6C). These intraclasts consists of reworked angulose microbial laminite fragments derived from the underling bed. Intraclast sizes between 1 and $3 \mathrm{~cm}$ are common. Cycles thickness varies from 10 to $33 \mathrm{~cm}$ with $15 \mathrm{~cm}$ in average. The entire cycle thickness records upward shallowing patterns. Both types of cycles might be considered as complete cycles.

\subsubsection{Cycle B-3}

These cycles are characterized by a discontinuous subtidal basal lag constituted by flat-pebbles derived from the microbial laminite layers at the top of the underlying cycle (Fig. 6D). They pass to laminated mudstones from the subtidal setting and are followed by more restricted facies represented by planar to crinkle microbial beds with different features related to subaerial exposures. Tepee horizons are common. The cycles are capped by flat-pebble con-glomerates. Cycles vary in thickness from 10 to $35 \mathrm{~cm}$ with a mean of $17 \mathrm{~cm}$.

\subsubsection{Cycle B-4}

The cycles start on an irregular surface which is overlain by planar to crinkle microbial laminate beds followed by intertidal laminated or massive mudstones with evaporite pseudomorph crystals (Fig. 6E). Cycles are capped by flat-pebble conglomerates. 
Angulose intraclasts among $2 \mathrm{e} 4 \mathrm{~cm}$ in size are planar, and in some cases show imbrications. These intraclasts consist of reworked fragments derived from the underlain bed (microbial laminites and mudstones). Variation in this cycle organization is represented by cycles B-5 (Fig. 6F) which are capped by intraclastic breccias. They are $7 \mathrm{e} 20 \mathrm{~cm}$ in thickness with a mean of $13 \mathrm{~cm}$. The entire cycle records an upward shallowing facies succession capped by flat-pebble conglomerates or features which indicate subaerial exposure. Both cycles may be considered as incomplete cycles.

\subsection{Fischer plot analysis}

Fischer plots of cyclic peritidal successions provide a simple and objective method for illustrating deviations of individual cycle thickness from the average cycle thickness through stratigraphic successions (Fischer, 1964). These are diagrams in which cumula-tive departure from the average cycle thickness of the section, which is usually a proxy for accommodation change, is plotted against cycle number, often interpreted as a proxy for time ("orig-inal" Fischer plots), or alternatively, against cumulative cycle thickness ("modified" Fischer plots). Details of the method can be found in Sadler et al. (1993), Day (1997), and Martín Chivelet et al.(2000).

In this paper Fischer plots have been performed for Arroyo La Manga , Yeseras Grandes and Los Blancos sections (Fig. 7). The microstratigraphic analysis has allow us to recognized 77 elemen-tary cycles in Los Blancos, 46 in Arroyo La Manga, and 27 in Yeseras Grandes. The outcrop sections from Arroyo La Vaina and Codo del Blanco were used as control points of the variation in the thickness of the cycles, facies distribution and changes in accommodation space.

In the three studied sections a lower subtidal cycle interval is recognized. This is represented by marls, laminated mudstones and intraclastic wackestone. In Arroyo La Manga and Yeseras Grandes, cycles show an increase in their thickness that suggest a relatively major accommodation space, where carbonate production was enough to fill the available space (e.g., Strasser et al., 1999). How-ever, in the Los Blancos section cycles are thinner than average cycles, which could be accepted as a phase of reducing accommo-dation space. A progressive shallowing-upward trend is observed because of facies variations. Likewise, plenty of intraclasts derived

s
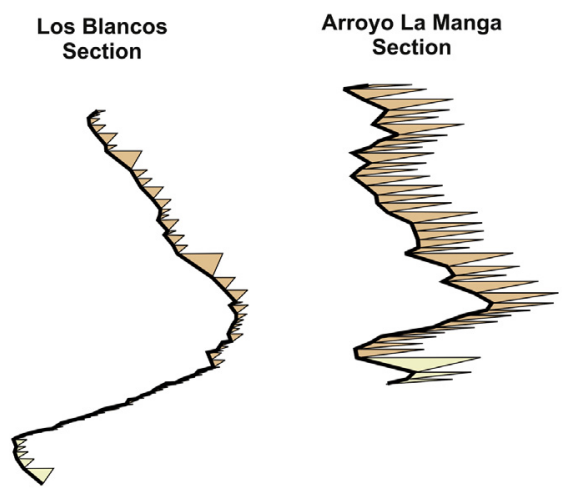

Shallow subtidal cycles

Intertidal - supratidal cycles

Fig. 7. Fischer plot showing variations in cycle thickness within the Unit 2 of La Manga Formation. Vertical scale represents sedimentary cumulative thickness ("modified Fischer plots" according Martín Chivelet et al., 2000). Horizontal scale has been exaggerated in order to enhance relative changes in accommodation. from the reworking of underlying facies are common so that the upper part of these cycles may have been eroded. According to Osleger (1991) an autocyclic model can not be invoked for the formation of subtidal cycles due to the absence of tidal flat cap.

In the three localities overall similarities appear in the intertidalsupratidal sections, which are characterized by a remarkable diminution of cycle thicknesses and decreasing ac-commodation space. In this way, it would be considered that variation in the stacking patterns of the cycles may be related to differences in the sedimentation rate. Nevertheless, a widespread developed of microbial laminites in Yeseras Grandes might have been influenced by a decrease of shallow marine production (cf. Baud et al., 1997) and by elevated saturation state of calcium car-bonate in seawater (Riding and Liang, 2005).

These cycles appear always capped by exposure features. Moreover, the abundance of flat-pebble conglomerates and intra-clastic breccias also reflects erosion processes associated with decreasing in the accommodation space. The well preserved intraclastic breccia (autoclastic breccia) suggests desiccation, early lithification and minimal erosion of the microbial communities before next cycle deposition. Subaerial exposures features probably would be controlled by sea-level oscillations. Nevertheless, the shoaling-upward trend, regardless of the presence of tepee struc-tures, has been related to autocyclic mechanisms (e.g., Grotzinger, 1986; Bosellini and Hardie, 1988; Pomoni-Papaioannou and Kos-topoulou, 2008).

The top of the Yeseras Grandes, Arroyo La Manga and los Blancos sedimentary sections are characterized by the presence of paleo-karst breccias and abnormal thickness beds were observed. Paleo-karst breccias appear through out the intertidal-supratidal sections, interbedded in some cases, with thin planar microbial laminites. Those breccia represent a non-cyclic intervals, therefore Fischer's method should not be applied in this stratigraphical interval. Moreover, a decrease of accommodation space influenced by allo-cyclic processes may be the answer to a sea-level fall concomitant with a lower rate of sedimentation.

The north-south transect from the La Manga ramp deposits (section at Las Yeseras passing through Arroyo La Manga to the Los Blancos area) shows the general decrease in cycles thickness to-wards the south. Even though individual cycles may not be trace-able from one section to another, there is a suggestion that water depth was certainly fluctuating and there is a general shallowing trend recognized in all the studied sections.

The presence of a thicker succession for Unit 2, as well as a larger number of small-scale cycles in Los Blancos area in opposition to Yeseras Grandes and the Arroyo La Manga sections suggests that Los Blancos section was more restricted. Los Blancos area was located on a paleo-high or nearer to the shoreline, where more intertidalsupratidal facies are recognized (cf. Tucker and Garland, 2010).

The remarkable cycle discontinuities are related to sea-level fluctuations (cf. Adams and Grotzinger, 1996) even though a local subsidence can not rule out (Hamon and Merzeraud, 2008). As Bádenas et al. (2010) suggest, the lateral continuity of cycles can be controlled by depositional topography or by local subsi-dence, where facies distribution results from production rate and accumulation. Evidence of sea level fall was reported by Palma et al.(2010, 2011) because of the presence of paleokarstic breccias facies.

Sea-level change on carbonate succession driven by faultrelated generation of accommodation space has mentioned by Cisne (1986) and Hardie et al. (1991). Studies performed by Rosales et al. (1994) in the Albian of northwestern Spain and those made by Bosence et al. (1998) in the Miocene of the Gulf of Suez showed that cycles are formed in response to the accommodation space gener-ated from fault-block movement. More recently De Benedictis et al.(2007) suggest that fault movements can generate the required 
accommodation space, at the required frequency, and senses of movement for the development of metre-scale, peritidal carbonate parasequences (PCPs).

According to De Benedictis et al. (2007) the main cycles showed an asymmetric shallowing-up and symmetric shallowedeepe shallow stacking patterns. Therefore in our case study the tectonic origin of shallowing cycles can be ruled out by the absence of ev-idence as suggested by the authors mentioned above.

Cycles controlled by eustatic sea level changes include lateral continuity of cycles on a regional scale (Koerschner and Read, 1989) that in our cases was not observed. Cycles from the suited sections show a shallowing upward tendence with different evidence of subaerial exposure. Taking into account the facies evolution, abundance of subaereal related features as well as a progressive decrease of accommodation space, changes of relative sea-level are accepted. Finally, the transition from La Manga Formation to Auquilco Formation is generally characterized by a paleokarst sur-face affecting the entire study area.

\section{Conclusions}

Stratigraphic knowledge based on Fischer plots, vertical facies evolution and sedimentary structures provides new data about the facies correlation, allowing to reach more precise paleoenvir-onmental interpretations. Shallow subtidal and intertidal-supratidal cycles were recognized.

Shallow subtidal cycles are composed by marls, laminated or massive mudstones or bioclastic wackestones and intraclastic wackestoneepackstones. Four different types of cycles would correspond to intertidal-supratidal facies. The most frequent starts with a planar erosion surface overlain by thin marls or massive mudstones, followed by intraclastic wackestones and capped by microbial laminites with fenestrae, mud-cracks, sheet-cracks and flat-pebble conglomerates, teppes or intraclastic breccias, showing a clear regressive arrangement.

The study of these cycles let recognized changes in accommo-dation space. The increase in subtidal cycle thicknesses in Arroyo La Manga and Yeseras Grandes suggest a relatively major accommo-dation space. Subtidal cycles in the Los Blancos section are thinner than average, suggesting a phase of reducing accommodation space. These cycles would be produced by changes of depositional environment controlled by fluctuations in sea-level. Taking into account the facies evolution, cyclicity, plenty of related subaerial-related features and development of paleokarst levels changes of relative sea level are accepted. In the studied localities, the intervals studied are capped by paleokarst breccias, which is related with a sea-level fall.

\section{Acknowledgements}

We are indebted to Alberto Riccardi for the identification of the ammonites. This research was supported by the Consejo Nacional de Investigaciones Científicas y Técnicas- PIP- 0546 and UBACyT 01/XC28. We benefited from the insightful manuscript reviews by Beatriz Bádenas, and anonymous reviewer. We are gratefull to Andrea Concheyro for the identification of coccolithophorids. Thanks are given to Juan C. Poblete for their assistance in field work. This is the contribution R-68 of the Instituto de Estudios Andinos Don Pablo Groeber (IDEAN).

\section{References}

Adams, R.D., Grotzinger, J.P., 1996. Lateral continuity of facies and parasequences in Middle Cambrian platform carbonates, Carrara Formation, southeastern California, USA. Journal of Sedimentary Petrology 66, 1079e1090.
Assereto, R.L., Kendall, C.G., 1977. Nature, origin and classification of peritidal tepee structures and related breccias. Sedimentology 24, 153e210.

Bádenas, B., Aurell, M., Bosence, D., 2010. Continuity and facies heterogeneities of shallow carbonate ramp cycles (Sinemurian. Lower Jurassic, North-east Spain. Sedimentology 57, 1021e1048.

Baud, A., Cirilli, S., Marcoux, J., 1997. Biotic response to mass extinction: the lowermost Triassic microbialites. In: Neuweiler, F., Reitner, J., Monty, C. (Eds.), Biosedimentology of Microbial Buildups, IGCP Project No. 380, Facies 36, pp. $238 \mathrm{e} 242$.

Bosellini, A., Hardie, L.A., 1988. Facies e cicli della Dolomia Principale delle Alpi Venete. Memorie della Società Geologica Italiana 30, 245e266.

Bosence, D.W.J., Cross, N., Hardy, S., 1998. Architecture and depositional sequences of tertiary fault-block carbonate platforms; an analysis from outcrop (Miocene, Gulf of Suez) and computer modelling. Marine Petroleum Geolo-gists $15,203 \mathrm{e} 221$.

Bressan, G.S., Palma, R.M., 2010. Taphonomic analysis of fossil concentrations from La Manga Formation (Oxfordian), Neuquén Basin, Mendoza Province, Argentina. Journal of Iberian Geology 36, 55e 71.

Carillat, A., Martini, R., Zaninetti, L., Cirilli, S., Gandin, A., Vrielynck, B., 1999. The Muschelkalk (Middle to Upper Triassic) of the Monte di Santa Giusta (NW Sardinia): sedimentology and biostratigraphy. Eclogae Geologicae Helvetiae 92, 81e97.

Carpentier, C., Lathuilière, B., Ferry, S., 2010. Sequential and climatic framework of the growth and demise of a carbonate platform: implications for the peritidal cycles (Late Jurassic, North-eastern France). Sedimentology 57, 985e1020. Cisne, J.L., 1986. Earthquakes recorded stratigraphically on carbonate platforms. Nature 323, 320e322.

Davies, G.R., 1970. Algal-laminated sediments, Gladstone Embayment, Shark Bay, Western Australia. American Association of Petroleum Geologists Bulletin 13, $169 \mathrm{e} 205$.

Day, P.I., 1997. The Fischer diagram in the depth domain: a tool for sequence stratigraphy. Journal of Sedimentary Research 67, 982e984.

De Benedictis, D., Bosence, D., Waltham, D., 2007. Tectonic control on peritidal carbonate parasequence formation: an investigation using forward tectonostratigraphic modeling. Sedimentology 54, 587e605.

Dean, W.E., Anderson, R.Y., 1982. Continuous subaqueous deposition of the Permian Castile evaporites, Delaware Basin, Texas and New Mexico. Core Workshop n ${ }^{\circ}$. In: Handford, C.R., Loucks, R.G., Davies, G.R. (Eds.), Depositional and Diagenesis Spectra of Evaporites. Society Economics Paleontologists Mineralogist, Calgary, Canada, pp. $324 \mathrm{e} 353$.

Demicco, R.V., Hardie, L.A., 1994. Sedimentary Structures and Early Diagenetic Features of Shallow Marine Carbonate Deposits. Atlas series 1. Society for Sedimentary Geology, Tulsa, p. 265.

Fischer, A.G., 1964. The Lofer cyclothems in the Alpine Triassic. Kansas Geological Survey Bulletin 169, 107e149.

Friedmann, G.M., Sneh, A., Owen, R.W., 1985. The Ras Muhammad Pool: Implications for the Gavish Sabkha. In: Friedmann, G.M., Krumbein, W.E. (Eds.), Hypersaline Ecosystems, The Gavish Sabkha, Ecological Studies, 53. Springer-Verlag, Berlin, pp. $218 \mathrm{e} 237$.

Gebelein, C.D., 1976. The effects of the physical, chemical and biological evolution of the earth. In: Walter, M.R. (Ed.), Stromatolites, Developments in Sedimentology, 20. Elsevier, pp. 499e 515.

Giambiagi, L., Bechis, F., Lanés, S., Tunik, M., García, V., Suriano, J., Mescua, J., 2008. Formación y evolución Triásico-Jurásica del depocentro Atuel, Cuenca Neu-quina, provincia de Mendoza. Revista de la Asociación Geológica Argentina 63, 520e533.

Ginsburg, R.N., 1971. Landward Movement of Carbonate Mud: New Model for Regressive Cycles in Carbonates (Abstract). American Association of Petroleum Geologists, p. 340. Annual Meeting, Abstracts with Programs.

Goldhammer, R.K., Dunn, P.A., Hardie, L.A., 1987. High frequency glacio-eustatic oscillations with Milankovitch characteristics recorded in northern Italy. American Journal of Science 287, 853e892.

Groeber, P., 1946. Observaciones geológicas a lo largo del meridiano 70. Hoja Chos Malal. Revista de la Asociación Geológica Argentina 1, 177e206.

Groeber, P., Stipanicic, P.N., Mingramm, R.G., 1953. Jurásico. In: Groeber, P., Stipanicic, P.N., Mingramm, R.G. (Eds.), 1953. Geografía de la República Argentina, II. GAEA, pp. 143e347.

Grotzinger, P., 1986. Cyclicity and paleoenvironmental dynamics, Rocknest platform, northwest Canada. Geological Society American Bulletin 97, 1208e1231.

Grover Jr., G., Read, J.F., 1978. Fenestral and associated vadose diagenetic fabrics of tidal flat carbonates, Middle Ordovician New Market limestone, southwestern Virginia. Journal of Sedimentary Petrology 48, 453e473.

Hamon, Y., Merzeraud, G., 2008. Facies architecture and cyclicity in a mosaic carbonate platform: effects of fault-block tectonics (Lower Lias, Causses platform, southeast France). Sedimentology 55, 155e178.

Hardie, L.A., Dunn, P.A., Goldhammer, R.K., 1991. Field and modelling studies of Cambrian carbonate cycles, Virginia Appalachian e a discussion. Journal of Sedimentary Petrology 61, 636e646.

Husinec, A., Read, J.F., 2011. Microbial laminite versus rooted and burrowed caps on peritidal cycles: salinity control on parasequence development, Early Creta-ceous isolated carbonate platform, Croatia. Geological Society of American Bulletin 123, $1896 \mathrm{e} 1907$.

Kendall, C.G.St.C., Skipwith, P.A.D.E., 1969. Recent algal mats in a Persian Gulf lagoon. Journal of Sedimentary Petrology 38, 1040e1058. 
Kendall, C.G., St.C., Warren, J.K., 1987. A review of the origin and setting of tepees and their associated fabrics. Sedimentology 34, 1007e1027.

Koerschner, W.F.I.I., Read, J.F., 1989. Field and modelling studies of cambrian carbonates cycles, Virginia appalachians. Journal of Sedimentary Petrology 59 , $654 \mathrm{e} 687$.

Leanza, H.A., 1981. The JurassiceCretaceous boundary beds in west-central Argentina and their ammonite zones. Neues Jahrbuch für Geologie und Paläontologie. Abhandlungen 161, 62e92.

Legarreta, L. 1991. Evolution of a Callovian-Oxfordian carbonate margin in the Neuquen Basin of the west-central Argentina: facies, architecture, depositional sequences and global sea-level changes. Sedimentary Geology 70, 209e240. Legarreta,

L., Gulisano, C.A., 1989. Análisis estratigráfico secuencial de la Cuenca

Neuquina (Triásico Superior- Terciario Inferior), Argentina. In: Chebli, G.A., Spalletti, L.A. (Eds.), Cuencas Sedimentarias Argentinas, Simposio Cuencas Sedimentarias Argentinas, Serie Correlación Geológica, 6, pp. $221 \mathrm{e} 243$.

Lo Forte, G., Palma, R.M., 2002. Facies, microfacies and diagenesis of late Callovian e early Oxfordian carbonates (La Manga Formation) in the west-central Argentinian High Andes. Carbonates and Evaporites 17, 1e16.

Manceda, R., Figueroa, D., 1995. Inversion of the mesozoic Neuquén Rift in the Malargüe Fold and thrust Belt, Mendoza. Argentina. In: Tankard, A.J., Suárez Soruco, R., Welsink, H.J. (Eds.), 1995. Petroleum Basins of South America, 62. American Association of Petroleum Geologists Memoir, pp. 369e382.

Martín Chivelet, J., Osleger, D.A., Montañez, I.P., 2000. Modified Fischer plots as graphical tools for evaluating thickness patterns in stratigraphic successions. Journal of Geoscience Education 48, 179e183.

Mitchum Jr., R.M., Uliana, M.A., 1985. Seismic stratigraphy of carbonate depositiona sequences, upper Jurassic-lower Cretaceous. Neuquén Basin, Argentina. In: Berg, R.B., Woolverton, D.G. (Eds.), 1985. Seismic Stratigraphy: an Integrated Approach to Hydrocarbon Exploration, 39. American Association of Petroleum Geologists Memoir, pp. 255e274

Osleger, D.A., 1991. Subtidal carbonate cycles; implications for allocyclic vs. autocyclic controls. Geology 19, 917e920.

Palma, R.M., Kietzmann, D.A., 2008. Ciclos de somerización en facies peritidales de la Formación La Manga: tipos, origen y controles. In: XII Reunión Argentina de Sedimentología, p. 133. Resúmenes.

Palma, R., Lo Forte, G., Lanés, S., 1997. Diagenesis of the lower Callovian Member of La Manga Formation, Aconcagua Basin, Mendoza, Argentina. In: 18th Regional European Meeting of Sedimentology, Heidelbergensis, pp. 260e263.

Palma, R.M., López Gómez, J., Piethé, R.D., 2007. Oxfordian ramp system (La Manga Formation) in the Bardas Blancas area (Mendoza Province), Neuquén Basin, Argentina: facies and depositional sequences. Sedimentary Geology 195, 113e134.

Palma, R.M., Kietzmann, D.A., Adamonis, S., López Gómez, J., 2009. Oxfordian reef architecture of the La Manga Formation, Neuquén Basin, Mendoza Province, Argentina. Sedimentary Geology 221, 127e140.

Palma, R.M., Kietzmann, D.A., Martín-Chivelet, J., López-Gómez, J., Bressan, G.S., 2010. Lower Callovian-Middle Oxfordian facies from the La Manga Formation carbonate ramp: a forced regression. Atuel Depocenter, Neuquén Basin, Men-doza Province, Argentina. The 8th International Congress on the Jurassic Sys-tem, Sichuan, China. Earth Science Frontiers 17, 203e303.
Palma, R.M., Riccardi, A.C., Kietzmann, D.A., Martín-Chivelet, J., López-Gómez, J., Bressan, G.S., 2011. Depósitos carbonáticos de la Formación La Manga (Caloviano inferior e Oxfordiano medio): evidencias de regresión forzada. Depocentro Atuel, Mendoza, Cuenca Neuquina. In: XVIII Congreso Geológico Argentino, Actas CD, pp. 907e908.

Palma, R.M., Kietzmann, D.A., Martín-Chivelet, J., López-Gómez, J., Bressan, G.S 2012. New biostratigraphic data from the Callovian-Oxfordian La Manga For-mation, Neuquén Basin, Argentina: Evidence from an ammonite condensed level. Revue de Paléobiologie 11, 345e356.

Pomoni-Papaioannou, F., Kostopoulou, V., 2008. Microfacies and cycles stacking pattern in Liassic peritidal carbonate platform strata, Gavrovo-Tripolitza platform, Peloponnesus, Greece. Facies 54, 417e431

Pratt, B.R., 2010. Peritidal carbonates. In: James, N.P., Dalrymple, R.W. (Eds.), Facies Models 4, GEOtext4. Geological Association of Canada, pp. 401e420.

Reid, R.P., Foster, J.S., Radtke, G., Golubic, S., 2011. Modern Marine Stromatolites of Little Darby Island, Exuma Archipelago, Bahamas: environmental setting, ac-cretion mechanisms and role of Euendoliths. Advances in Stromatolite Geobiology. Lecture Notes in Earth Sciences 131, 77e89.

Riccardi, A.C., 1984. Las asociaciones de amonitas del Jurásico y Cretácico de Argentina. In: IX Congreso Geológico Argentino, Actas 4, pp. 559e595. Riccardi,

A.C., 1992. Biostratigraphy of west-central Argentina. In: Westermann, G.E.G. (Ed.), The Jurassic of the Circum-Pacific. Cambridge University Press, pp. 139e141. Riccardi,

C.A., 2008. El Jurásico de la Argentina y sus amonites. Revista de la Asociación Geológica Argentina 63, 625e643.

Riding, R., Liang, L., 2005. Geobiology of microbial carbonates: metazoan and seawater saturation state influences on secular trends during the Phanerozoic. Palaeogeography, Palaeoclimatology, Palaeoecology 219, 101e115.

Rosales, I., Fernandez-Mendiola, A., Garcia-Mondejar, J., 1994. Carbonate depositional sequence development on active fault-blocks: the Albian in the Castro-Urdiales area, northern Spain. Sedimentology 41, 861e882.

Sadler, P.M., Osleger, D.A., Montañez, I., 1993. On the labeling, length and objective basis of Fischer plots. Journal of Sedimentary Petrology 63, 360e368. Schlager, W.

2003. Benthic carbonate factories of the Phanerozoic. International Journal Earth Sciences 92, 445e464.

Shinn, E.A., 1983. Tidal flats. In: Scholle, P.A., Bebout, D.G., Moore, C.H. (Eds.), 1983 Carbonate Depositional Environments, 33. American Association of Petroleum Geologists Memoir, pp. 171e210.

Stipanicic, P.N., 1965. El Jurásico de la Vega de la Veranada (Neuquén, el Oxfordense y el diastrofismo divesiano (Agassiz-Yaila) en Argentina. Revista de la Asocia-ción Geológica Argentina 20, 403e478.

Strasser, A., Pittet, B., Hillgartner, H., Pasquier, J.B., 1999. Depositional sequences in shallow carbonate-dominate sedimentary systems: concepts for highresolution analysis. Sedimentary Geology 128, 201e222.

Tucker, M., Garland, J., 2010. High frequency cycles and their sequence stratigraphic context: orbital forcing and tectonic controls on Devonian cyclicity, Belgium. Geologica Belgica 13, 213e240.

Warren, J.K., 1982. The hydrological significance of Holocene tepees, stromatolites and box work limestones in coastal salinas in South Australia. Journal of Sedimentary Petrology 52, 1171e1201. 